\title{
Les alqueries del terme de Borriana
}

\author{
Ivan Cabrerai Fausto (ivcabfau@mes.upv.es) \\ ERnesto Fenollosa Forner (efenollo@mes.upv.es) \\ Begoña Serrano Lanzarote (begserlan@mes.upv.es) \\ RicARdo Perelló Roso (rperello@mes.upv.es) \\ Universitat Politècnica de València
}

\section{Introducció}

La ciutadania de Borriana és prou conscient de l'important patrimoni arquitectònic que atresora el municipi. Però eixa consciència sol centrar-se, freqüentment i quasi exclusivament, en edificis o espais situats al nucli urbà i amb una càrrega històrica $o$ ornamental significativa. Tanmateix, al terme encara podem trobar exemples magnífics de construccions de tot tipus que han estat testimoni de la nostra història i són part de la nostra cultura.

Des de la seua fundació, Borriana ha tingut una molt intensa relació amb els camps que l'envoltaven arran de les amplíssimes possibilitats agrícoles que aquest medi proporcionava gràcies a la seua gran fertilitat. De fet, el nucli urbà tenia bàsicament el paper d'element aglutinador d'eixe potent entorn agrari (Torrent i Pla, 1987: 317). Les condicions geogràfiques, edafològiques, hidrològiques i climatològiques van propiciar una agricultura intensiva ${ }^{1}$ que ha arribat als nostres dies distribuïda en un mosaic de xicotetes explotacions que han estat històricament propietat de les famílies que les treballaven. L'inevitable i progressiva antropització ${ }^{2}$ d'aquest medi natural ha anat configurant segle rere segle el nostre paisatge com una gran catifa verda esquitxada d'exemples d'arquitectura rural de molts tipus on destaquen, per la seua densitat, les alqueries (Mesado, 1991: 187).

La colonització intensiva del nostre medi natural comença durant l'època musulmana arran de la introducció del regadiu i el consegüent augment de les possibilitats i productivitat de les explotacions agràries. Els documents del repartiment posteriors a la conquesta cristiana recullen nombrosos exemples de llogarets i alqueries que depenien de la vila (Guixard, 1987: 76). A la segona meitat del segle XIII, fins i tot després de la segregació necessària per la fundació de la veïna Vila-real, ${ }^{3}$ el nostre terme acollia més de 300 cases de conreu (Mesado, 1991: 187). A l'edat mitjana, el recinte intramurs de la vila era de dimensions molt modestes, amb una capacitat limitada d'acollir població. Fins i tot, alguns edificis que actualment estan perfectament acomodats en la nostra trama urbana

\footnotetext{
${ }^{1}$ La ramaderia ha tingut històricament menys importància al nostre municipi, atés que estava enfocada fonamentalment a l'autoabastiment.

${ }^{2}$ Entenem com antropització la transformació que els éssers humans fan del medi natural per adaptar-lo a les seues necessitats i desitjos.

${ }^{3}$ El rei Jaume I atorga carta pobla fundacional a Vila-real l'any 1274, que incloïa la segregació de part del terme municipal de Borriana.
} 


\section{Exla Cbrongca o datencla. Cree la pilla de Buriang.}

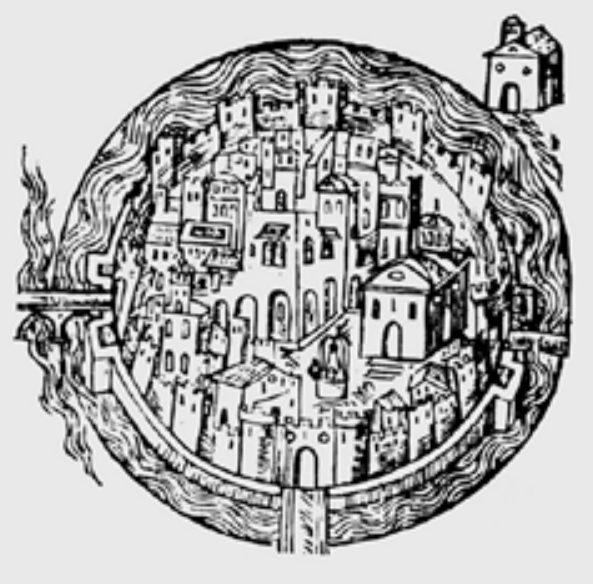

Figura 1.Il-lustració que representa la vila de Borriana a la Crónica de la ínclita y coronada ciudad de Valencia escrita per Rafel Martí de Viciana al segle XVI.

van nàixer com a elements aillats extramurs. Aquest és el cas de l'ermita de Sant Mateu (fig. 1), germen de l'actual església i convent de la Mercè, i de l'ermita de Sant Blai.

A l'edat moderna, l'aparició dels ravals catalitza una progressiva migració de la població rural cap al poble, per la qual cosa augmenta de manera progressiva el percentatge de població urbana. Al segle XVIII el cens recollia al nostre terme només seixanta alqueries, molins o caserius (Torrent i Pla, 1987: 323), on hi vivien 375 persones, que representaven tan sols el $12,05 \%$ de la població de la Borriana de l'època (Torrent i Pla, 1991: 282).

La introducció del conreu de la taronja a les acaballes del segle xix i principis del segle xx comportarà un important augment de la població que, combinat amb la rendibilitat econòmica de la producció de cítrics, tornarà a omplir els camps de població permanent $\mathrm{i}$ els farà viure un dels seus episodis daurats. Tot i això, diversos esdeveniments del segle xx, com ara la Guerra Civil i l'arribada de les indústries, propiciarà una nova i inexorable migració de la població cap a la ciutat. Les alqueries esdevindran una opció habitacional cada vegada menys atractiva i aniran abandonant-se progressivament. El percentatge de població que actualment les fa servir per a viure-hi tot l'any és molt reduït. Però és cert que moltes s'han reconvertit en habitatges d'estiu, majoritàriament desvinculades de les explotacions agràries que les envolten.

\section{Els orígens de la tipologia}

D'acord amb els diccionaris i compendis actuals, com ara la Gran Enciclopèdia Catalana, la paraula «alqueria» ve de l'àrab al-qàrya i fa referència a un llogaret habitat. El significat d'aquest mot, per tant, ha anat evolucionant al llarg de la història. Originalment s'aplicava a qualsevol poblat diferent de la vila o plaça forta (Martínez, 1951). El terme alqueria va anar fent-se específic per a designar el lloc on habitaven els propietaris de les modestes explotacions agrícoles que l'envoltaven, diferenciant-se així clarament d'un rafal, que era una finca molt més gran pertanyent a algun noble o personatge poderós que vivia a la vila i on habitaven només els seus treballadors (Guixard, 1987: 76). Després de la conquesta de Borriana, el rei Jaume I va fer donació de diverses alqueries existents al terme en favor dels ordes militars que l'havien ajudat en la gesta. Algunes d'aquestes alqueries, com ara l'alqueria de Seca, van rebre pocs anys després carta pobla pròpia (García Edo, 1991: 89). Aquest fet posa de manifest com a l'època s'entenia alqueria no com un edifici 
únic i aîllat, sinó com un conjunt d'edificis més o menys agrupats, situats al terme i separats de la vila. Actualment, l'aplicació d'aquest mot a una agrupació d'edificis és més estranya, i entenem com a alqueria una casa de camp destinada al conreu fonamentalment agrícola i que està habitada durant tot l'any o durant àmplies temporades vinculades a certes tasques, com ara la collita. Aquesta tipologia edificatòria i les activitats que li són pròpies estan tan arrelades a la nostra història i la nostra cultura que la paraula «alqueria» ha romàs sense alteracions en la nostra llengua durant segles. Així mateix, cal mencionar com a curiositat que una de les especificitats de la parla de Borriana és fer servir aquesta paraula sense pronunciar la «e».

Al territori valencià, la cultura popular diferencia clarament l'alqueria del mas. L'alqueria se situa a les zones baixes de regadiu, mentre que el mas està situat a les zones àrides mitjanes i altes amb conreus de secà (Seijo, 1975: 11). Consegüentment, i possiblement introduïdes al nostre territori amb el regadiu durant l'època àrab, es popularitzaran en moltes comarques valencianes a partir del segle XVI i arribaran a la seua plenitud als segles XVIII, XIX i principis del segle XX (Del Rey, 2010: 13). Aquest període d'apogeu estarà propiciat pel creixement demogràfic, el desenvolupament econòmic i la consegüent transformació de la societat valenciana de l'època. El massiu assentament de població als camps del terme propiciarà l'estabilització d'aquesta tipologia arquitectònica a la qual responen la immensa majoria dels habitatges rurals que han arribat als nostres dies (Sanchis Guarner, 1981: 360).

\section{La morfologia de l'alqueria borrianenca}

L'alqueria borrianenca, seguint la tradició valenciana, sol ser un edifici de dimensions i proporcions generoses (Seijo, 1975: 45). L'edificació principal es defineix com un únic sòlid compacte, de planta normalment quadrada d'uns sis metres de costat, amb dues navades $\mathrm{i}$ amb dues plantes d'altura (Del Rey, 2010: 13). No solen tindre pati interior i al seu voltant poden afegir-se dependències annexes d'altura sempre inferior, com ara quadres, pallisses, assecadors o magatzems, que poden incorporar-se com a volums clarament diferenciats del sòlid principal deixant un pati o corral intermedi ${ }^{4} \mathrm{o}$ bé fusionar-se amb aquest (Del Rey, 2010: 17). Solen ser edificacions austeres i senzilles, però certament elegants arran de la puresa de la seua forma i l'harmonia visual aconseguida per la simetria, l'equilibri i el ritme dels seus elements. Aquestes característiques podem trobar-les també en altres exemples d'arquitectura rural europea (Kosanović i altres, 2019: 9).

Els escassos elements que interrompen la continuitat i sobrietat dels seus murs els trobem a la façana principal, normalment orientada cap a la mar per aprofitar el règim local de vents. A la Plana Baixa existeix un clar predomini de vents de l'est, sud-est i nordest (Vegas i Mileto, 2011: 56). Amb una oscillació tèrmica molt menys acusada que a les comarques de l'interior, els vespres i les nits de la costa són significativament calorosos i l'alliberament per part dels murs de la calor acumulada durant les hores de sol només empitjora la situació. Així doncs, les brises són l’única manera de refrescar els espais

\footnotetext{
${ }^{4} \mathrm{El}$ pati no és un element arquitectònic que articula els volums a costat i costat, sinó senzillament un espai buit entre les dues construccions (Del Rey, 2010: 17).
} 
interiors. Per a fer-les passar adequadament per l'interior de l'edifici és necessari orientar els màxims buits possibles en direcció a l'est i situar-ne d'altres a la façana oposada. Així doncs, les alqueries disposen els buits més grans i nombrosos a la façana principal orientada cap a la mar, altres buits també nombrosos però de dimensions més modestes a la façana posterior orientada cap a les muntanyes, i una absència de buits sovint total en les altres dues façanes laterals.

Les alqueries borrianenques presenten majoritàriament una coberta inclinada $\mathrm{a}$ dues aigües en el seu cos principal. Les edificacions annexes, separades d'aquest volum principal o ocasionalment adossades a aquest, presenten cobertes inclinades a una aigua (Vegas i Mileto, 2011: 105). L'opció de disposar els pendents de la coberta de manera paral-lela a la façana principal, de forma que vessen les aigües cap a les façanes laterals (fig. 2.A.1) és la més freqüent a Borriana, en consonància amb la resta del nord del territori valencià (Del Rey, 2010: 152). Aquesta opció presenta l'avantatge de poder reduir l'altura lliure de la planta alta (fig. 2.A.0), amb el consegüent estalvi de materials, sense comprometre excessivament les dimensiones dels buits de façana en aquesta planta, disposats per a rebre la llum del matí $i$ les brises durant la vesprada i la nit.

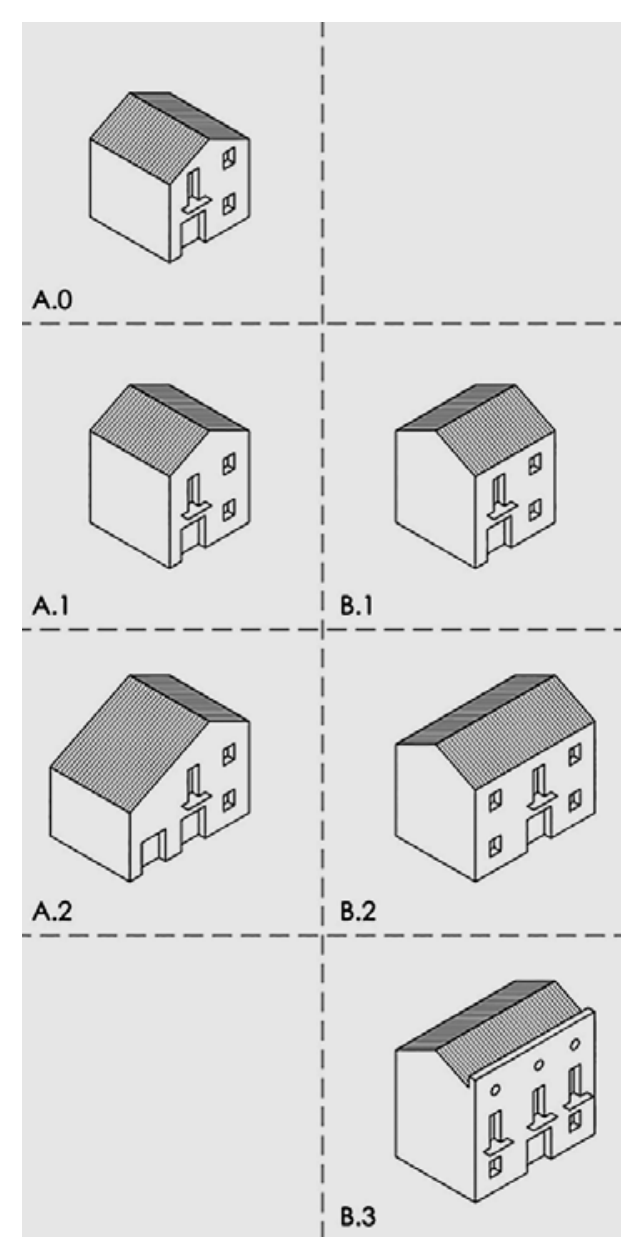

Figura 2. Recull de volumetries d'alqueries del terme de Borriana classificades d'acord amb l'orientació dels pendents de les cobertes.

Aquesta opció, al contrari, limita les possibilitats de la distribució interior de l'alqueria a l'opció d'una mà. Qualsevol afegit lateral alineat amb la façana no pot disposar mai de planta alta perquè s'ha de donar l'adequada continuïtat al pendent de la coberta (fig. 2.A.2). Així doncs, aquestes ampliacions són normalment destinades a quadres o magatzems, i no formen part de l'interior de l'habitatge tot i que, ocasionalment, poden estar comunicats interiorment mitjançant alguna portella.

Menys freqüents al nostre municipi i a la resta del nord valencià són les alqueries amb els pendents de la coberta parallels a les façanes laterals, de manera que vessen les aigües cap a la façana principal i la façana posterior (fig. 2.B.1). Aquesta opció no permet la reducció de l'alçària lliure de la planta alta sense comprometre les dimensions dels buits de la façana principal en eixa planta. Tanmateix, aquesta opció sí que permet optar per una 
distribució interior a dues mans (fig. 2.B.2), ja que el nou volum afegit a l'altre costat de la porta principal pot disposar de planta alta senzillament donant continuïtat a la coberta del volum principal. Parallelament, aquesta modalitat permet la construcció d'una tercera planta, coneguda a Borriana amb el curiós terme de «dalt del dalt». Aquesta planta disposa normalment d'una alçària molt menor i sol estar destinada a assecador o magatzem. Per a fer possible la circulació de terrals i brises, aquestes terceres plantes també disposen de buits oberts a la façana posterior i a la façana principal, la qual pot completar-se amb un ampit, amb la qual cosa tenen un aspecte molt semblant a les cases que poden trobar-se al nucli urbà (fig. 2.B.3). Finalment, cal afegir que aquesta

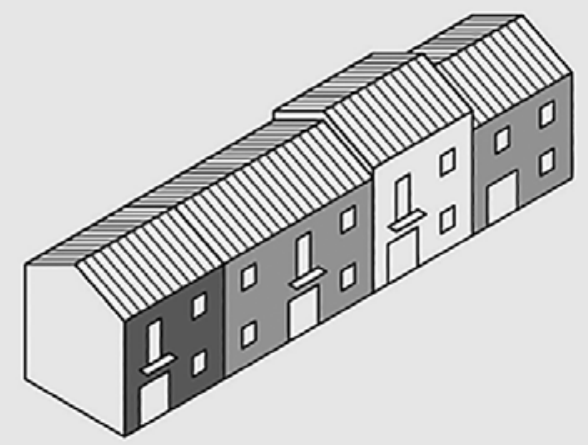
segona opció és l'única possible en el cas de panys o alineacions d'alqueries (fig. 3), ja que l'opció contrària faria vessar les aigües d'uns edificis damunt dels altres, amb els consegüents problemes de filtracions i humitats.

La distribució interior de les alqueries de Borriana és molt semblant a la de qualsevol casa a una o dues mans $\mathrm{s}^{5}$ del nucli urbà, amb l'única diferència de poder tindre en aquest cas un corral molt més ampli (Mesado, 1991: 187). La porta principal té entrada de carro alineada amb una altra ocasionalment de característiques semblants situada a la façana posterior, la qual cosa permet la circulació d'aquest vehicle, de ferramentes de gran envergadura o de bestiar cap al corral posterior (fig. 4). Passada la porta, trobem de seguida i a un costat la cambra on dormia el matrimoni propietari. A continuació, sol trobar-se l'escala que permet l'accés a la planta alta i, finalment, trobem l'espai de la llar on es cuinava ${ }^{6}$ i menjava a l'hivern. La llar sempre està construïda a l'interior de l'habitatge, sense minvar el gros del mur portant de la façana lateral. El fumeral discorre per l'intradós d'aquesta façana, tant en planta baixa com en planta alta, per tal d'aprofitarne al màxim la calentor als mesos més freds. La llar sempre està flanquejada per les prestatgeries del rebost i alguna de les parets laterals d'aquest espai acull el canterer. Alliberat del trànsit ocasional i convenientment netejat, l'espai passant central sovint tenia cadires i feia el paper de sala d'estar. Les dependències de la planta baixa del cos principal de la típica alqueria borrianenca poden estar ocasionalment connectades amb

\footnotetext{
${ }^{5}$ Anomenem casa o alqueria a una mà aquella on, travessant-la des de la porta del carrer fins a la porta del pati posterior, trobem cambres i estances només a un costat. L'amplària estàndard de la casa al nucli urbà és de sis metres, i a les alqueries del terme és semblant. De la mateixa manera, anomenem casa o alqueria a dues mans aquella on, travessant-la d'idèntica manera, trobem cambres i estances a tots dos costats. L'amplària estàndard al nucli urbà és de nou metres, i a les alqueries del terme també és semblant.

${ }^{6} \mathrm{~A}$ l'estiu i sempre que l'oratge ho permetia, era frequient cuinar en bancs exteriors. Moltes alqueries borrianenques encara conserven aquests bancs que, sostrats o no, són un clar antecedent dels actuals paellers.
} 
les estances d'altres volums afegits que poden proporcionar cambres addicionals o destinar-se a quadres.

La planta alta habitualment no està compartimentada (fig. 5) i la seua alçària no és tan generosa com la de la planta baixa (Del Rey, 2010: 159). Era l'espai on dormia la resta de la família o dels habitants de l'alqueria si no hi havia més cambres en la planta baixa. ${ }^{8}$ Aquest espai també es feia servir com a assecador, rebost o magatzem.

\section{Els materials i sistemes constructius}

Els fonaments de les alqueries del terme de Borriana solen estar fets amb els mateixos materials i sistema constructiu que els murs de càrrega sobre els quals

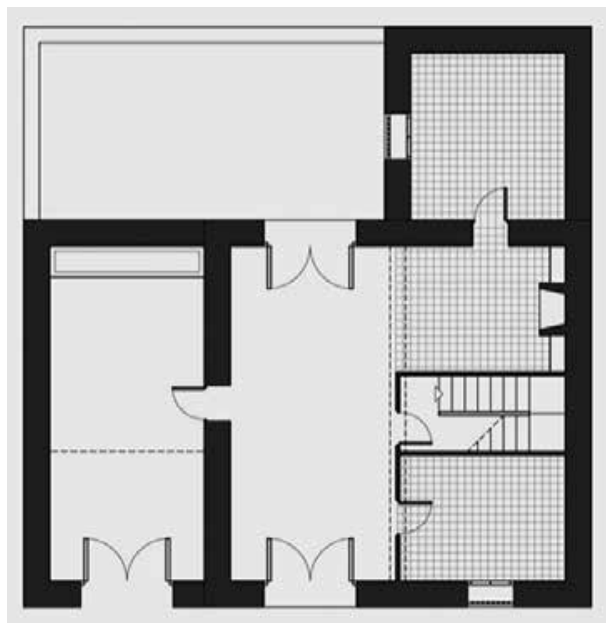

Figura 4. Plànol de distribució de la planta baixa de l'alqueria del Cuello? s'haurà de construir, però amb un ample lleugerament superior per a transmetre les càrregues correctament al sòl argilós que caracteritza el territori. Els murs de càrrega coincideixen amb les quatre façanes del volum principal i amb les façanes de qualsevol edificació auxiliar o annexa. Solen ser de tàpia feta amb la terra argilosa dels voltants (Vegas i Mileto, 2011: 106) amb freqüent inclusió de pedres de tota mida que queden de manifest quan l'escorrentia de les pluges arrossega els ocasionals revestiments o les capes exteriors de la terra. La seua grossària, d'un mig metre, permet l'absència de contraforts. Els exemples més recents o que al seu moment van disposar d'un major pressupost presenten filades de rajola o, fins i tot, murs fets completament de rajola presa amb morter de calç amb les mateixes característiques descrites, però amb una mètrica lleugerament menor gràcies al millor comportament d'aquest material. Les obertures a l'exterior són limitades (fig. 6) i es resolen mitjançant arcs rebaixats de rajola ceràmica i elements a flexió en fusta en el cas de buits de menor dimensió (Del Rey, 2010: 16). Com és habitual en qualsevol arquitectura rural, les qüestions ornamentals són escasses i epidèrmiques, i es redueixen a ocasionals enfoscats, pintures o detalls ceràmics que solen emprar-se només a la façana principal (Del Rey, 2010: 17) i són més habituals en els panys per a dotar d'individualitat cadascuna de les alqueries que els componen (fig.

\footnotetext{
${ }^{7}$ L'alqueria del Cuello estava situada a la vora del camí d'Almassora, a dos quilòmetres del nucli urbà de Borriana. Construïda possiblement a les acaballes del segle XIX, va ser habitada per la família Rosell generació rere generació. El matrimoni format per Vicent Rosell i Assumpció Ortells va criar allí els seus tres fills: Assumpció, Elvira i Vicent. Atemorits pels freqüents assalts i incidents que es produïen als habitatges aïllats del medi rural als inicis de la Guerra Civil, en van tancar les portes i van buscar la seguretat del poble comprant-se una casa al carrer d'Entença. Acabat el conflicte bèllic només hi van tornar per passar-hi alguns estius. A principis dels anys vuitanta, arran del risc imminent de collapse de la façana nord, la seua neta i el seu marit van decidir enderrocarla. És un exemple paradigmàtic d'alqueria borrianenca a una mà.

${ }^{8} \mathrm{~S}$ 'ha de considerar que no era estrany que en una mateixa alqueria visqueren diverses famílies emparentades entre si, o bé els propietaris i els treballadors.
} 


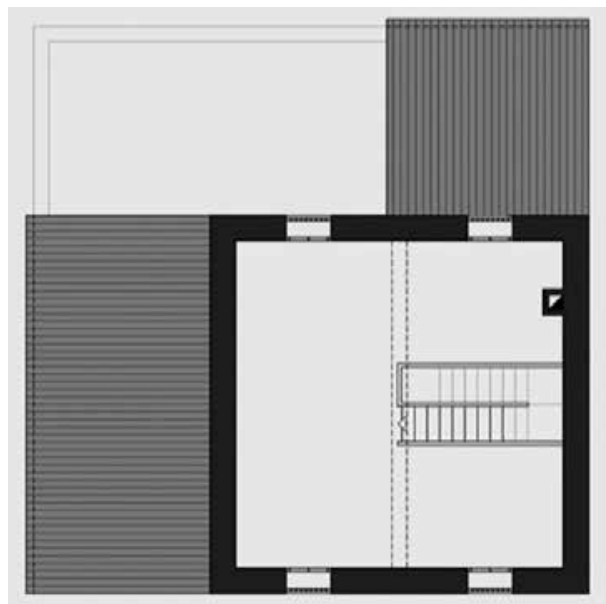

Figura 5. Plànol de distribució de la planta alta de l'alqueria del Cuello.

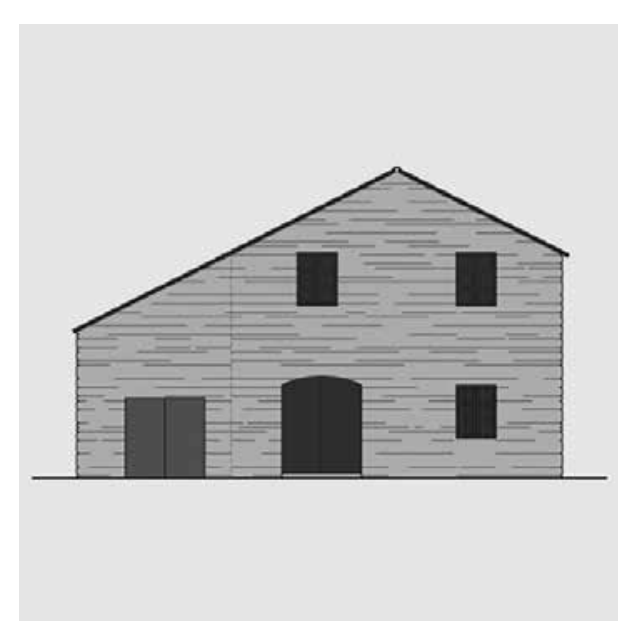

Figura 6. Façana principal de l'alqueria del Cuello.

3). A la nostra comarca aquests murs ocasionalment presenten socolades de pedra de Borriol o de pedra sorrenca roja d'Onda o Vilafamés (Bordils, 1998: 64).

El quadrat definit pels murs de càrrega es divideix en dues navades mitjançant una biga central de fusta, normalment de mobila, ${ }^{9}$ tant al forjat de terra de planta alta com al de coberta. Les biguetes en tots dos forjats també són de fusta, freqüentment de menor qualitat, disposades seguint el pendent de les cobertes (fig. 7). Els revoltons de rajola o canyís i guix recolzen sobre aquestes biguetes salvant intereixos ${ }^{10} \mathrm{amb}$ una amplària típica d'uns quaranta o cinquanta centímetres tot i que, sorprenentment, en exemples més antics trobem distàncies majors (Del Rey, 2010: 16). Sobre l'entrebigat es disposava un llit d'argila de vegades enriquida amb calç sobre el qual es disposaven les teules. L'estructura de les balconades a la nostra comarca es resol fonamentalment amb ferro senzillament fos o bé forjat (Vegas i Mileto, 2011: 87) i amb entrebigat de taulells ceràmics presos amb morter de calç. Finalment, les escales són de volta catalana feta amb rajola massissa de pocs centímetres de gruix presa amb escaiola almenys en la seua primera fulla, sovint l'única.

Les teulades es materialitzaven amb teules mores d'argila normalment deixades caure en sec sobre la superfície inclinada de la coberta. El color més habitual a Borriana és el siena torrada (Bordils, 1998: 28), un marró pàllid que contrasta meritòriament amb el verd fosc dels tarongers i l'intens blau del cel de la Plana (Bordils, 1998: 63). Els ràfecs, necessaris per a evitar que la freqüent absència de revestiments arrossegara la terra dels murs, es resolien amb rajoles primes o amb teula múltiple.

\footnotetext{
${ }^{9}$ La mobila no és cap espècie concreta. Normalment es tracta de fusta de pi melis o de roure que arribava a les nostres terres en vaixell des del port nord-americà de Mobile, situat a l'estat d'Alabama. L'etiquetatge d'aquest producte amb el nom del port d'origen i la valencianització del mot són l'origen del seu habitual nom, encara avui, per a designar qualsevol fusta antiga de gran qualitat.

${ }^{10} \mathrm{~S}$ 'anomena intereix la distància entre dues biguetes que ha de ser suportada pel revoltó o element d'entrebigat.
} 


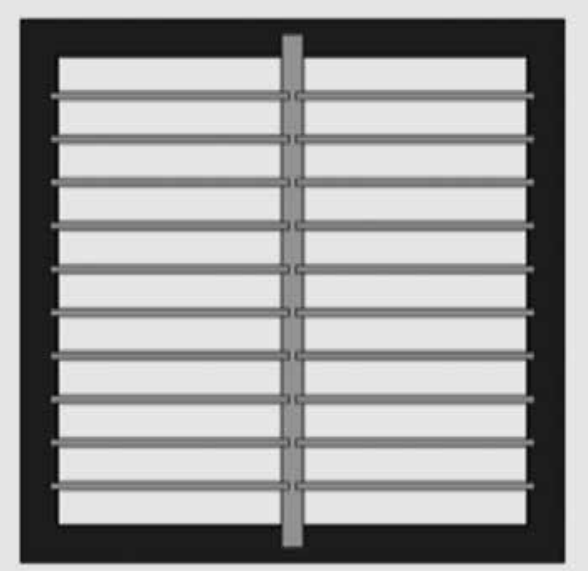

Figura 7. Estructura de la coberta del cos principal de l'alqueria del Cuello.

Aquestes mateixes rajoles massisses d'escàs gruix eren les que, col-locades de cantell, es feien servir per a materialitzar les distribucions interiors de la planta baixa (Vegas i Mileto, 2011: 106). Les portes i les finestres es feien de fusta de mobila amb color natural que anava variant a mesura que les peces envellien (Bordils, 1998: 64) i que amb el pas del temps acabava prenent una tonalitat semblant a la dels murs i cobertes. Les finestres eren freqüentment només fulles de fusta per a protegir i obscurir l'interior, i en el millor dels casos tenien vidres a l'exterior responent a la tipologia que coneixem com finestra catalana. A les alqueries borrianenques les reixes són fonamentalment funcionals $\mathrm{i}$ s'allotgen a l'interior del buit de la finestra, $i$ són molt escassos els llocs on sobreïxen del plànol de façana, circumstància bastant habitual en comarques meridionals del territori valencià.

A l'interior, a la planta baixa els paviments seran de terra piconada o morter, tot i que la cambra, l'escala i el menjador freqüentment presenten paviments hidràulics o ceràmics (fig. 4). A la planta alta, estranyament trobarem paviment i sovint xafem directament sobre el morter o les taules de fusta de l'entrebigat.

\section{La implantació al nostre territori}

El drenatge de les marjals i les operacions d'esplanació desenvolupades al nostre terme municipal per tal de dedicar fins a l'últim pam al llavors fructífer conreu del taronger ens han deixat com a herència un paisatge absolutament homogeni amb poques excepcions, com ara el Clot de la Mare de Déu. Aquesta homogeneïtat en la distribució de les explotacions agràries es tradueix en una també homogeneïtat en la distribució de les alqueries que acollien aquelles i aquells que vetlaven pels conreus. Així doncs, trobarem alqueries per qualsevol racó del terme municipal de Borriana. Tot i això, és ben cert que, amb l'excepció de l'alqueria de Carabona, la Regenta i l'alqueria del Baró (fig. 8), els exemples de major grandària i millor conservats es troben a la meitat nord del nostre terme. ${ }^{11}$

El cas més habitual d'alqueria és el d'una edificació totalment aïllada on vivia la família propietària de l'hort on se situa. El nostre terme també conserva nombrosíssimes construccions de semblants característiques però de menor mida i d'una sola planta destinades a l'emmagatzematge de ferramentes o l'acollida puntual de treballadors que necessitaven un lloc per a menjar o per a passar alguna nit, i que popularment es coneixen com alquerietes.

\footnotetext{
${ }^{11}$ La meitat nord del terme municipal de Borriana, especialment les partides que voregen el riu de Millars, presenta explotacions agrícoles i propietats de major extensió que les de la meitat sud, on el minifundi és molt més habitual.
} 


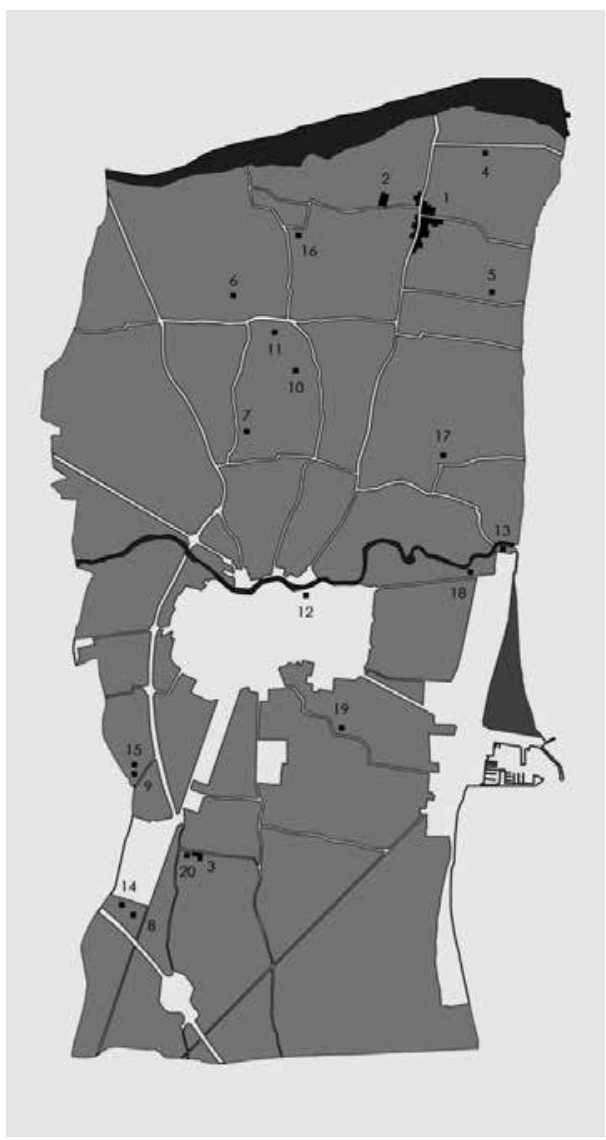

Figura 8. Plànol del medi rural del terme municipal de Borriana amb indicació de la posició de les agrupacions d'alqueries i conjunts edificats més rellevants, torres i ermites.
També és habitual trobar en algunes partides borrianenques polaritzacions d'alqueries, que arriben a agrupar-se formant panys, carrers o placetes enmig del terme. És el cas de les alqueries de Ferrer, situades a la meitat sud del nostre terme municipal, i les alqueries de Santa Bàrbara i el pany de Serra, situats a la meitat nord (fig. 9). Aquestes xicotetes aldees conserven avui en dia una salut envejable, especialment en el cas dels dos exemples septentrionals, i els seus propietaris les mantenen en perfecte estat, i passen allí llargues temporades que sovint excedeixen l'estiu. Aquests panys d'alqueries són el germen d'altres agrupacions totalment desvinculades del conreu de la terra, construïdes a partir de mitjans del segle $\mathrm{xx}$ i pensades estrictament per a passar l'estiu i fugir de la calor de la ciutat. És el cas d'alguns antics panys d'habitatges construïts a la zona de l'Arenal, la Malva-rosa i les Terrasses. En altres comarques valencianes, aquestes agrupacions d'alqueries van donar llocs a municipis tan rellevants com ara Alboraia, Algemesí, Burjassot, Canals, Catarroja, Mislata, Picassent, Puçol o Vinaròs. Altres, fins i tot, revelen en el seu nom el seu origen. És el cas de l'Alqueria d'Asnar i l'Alqueria de la Comtessa, a la província de València, o el nostre benvolgut municipi veí de les Alqueries.

Les primitives alqueries islàmiques sovint posseïen una torre que permetia els ocupants albirar el territori i defensar la plaça. Aquesta característica va ser heretada per diverses alqueries construïdes posteriorment a la conquesta cristiana afegint al seu rol d'habitatge de llauradors i colonització del territori la tasca defensiva. Al nostre terme són clars exemples d'aquesta casuística la torre de Carabona o la torre de Tadeo, entre altres (fig. 8). A l'edat moderna, aquestes alqueries fortificades evolucionaran cap al que anomenem alqueria senyorial, dotada de nombroses comoditats. Allí habitaven terratinents amb capacitat econòmica suficient per a llogar les persones que s'ocuparien de les seues explotacions agrícoles. A Borriana són clars exemples d'aquesta tipologia el Mas Quemado, la Regenta o l'alqueria del Baró, entre altres (fig. 8). Alguns d'aquests complexos es van reconvertir, disfressant les seues característiques originals i vinculació amb els conreus. El cas més conegut al nostre poble és el del Palaciet (fig. 8). Aquesta propietat, situada al camí de la Cantera, és fruit de la remodelació d'una antiga alqueria duta a terme poc abans 
de la Guerra Civil i que ha arribat als nostres dies com un dels exemples més singulars del corrent casticista de l'època al territori valencià (Benito Goerlich, 1987: 362).

\section{Problemàtica actual, possibilitats de futur i conclusions}

La modernització dels mètodes d'explotació agrària i la generalització de l'ús de vehicles de combustió durant el segle xx ha anat fent innecessària la presència continua dels llauradors a les terres conreades (Mesado, 1991: 1987). Les alqueries van començar a presentar-se com una tipologia d'habitatge caduca per les seues dimensions i característiques de les seues edificacions auxiliars (Seijo, 1975: 187). La població rural va sentir que el nucli urbà els oferia habitatges amb millors estàndards com ara electricitat, aigua corrent, clavegueram, etc., i un accés més còmode i immediat a botigues, collegis i altres serveis. L'abandonament gradual dels habitatges del medi rural, abans densament poblat, va propiciar la sensació d'inseguretat en les persones que inicialment hi havien decidit romandre, la qual cosa va motivar la marxa cap a la ciutat d'un gran percentatge d'aquestes per pura por. El cens del 28 de febrer de 1981 registrava un total de 1.081 alqueries al terme municipal de Borriana, les quals acollien tan sols 90 famílies, que es traduïen en només 282 habitants, un percentatge exigu de la població total del municipi a l'època (Mesado, 1991: 187). Viure al terme va tindre en certs períodes del segle xx connotacions negatives $i$, ocasionalment, va ser injustament relacionat amb la impossibilitat econòmica d'aquelles persones de mudar-se a la ciutat o amb un cert caràcter esquerp o marginal.

Els diferents plans generals que ha tingut la ciutat no van ajudar a millorar aquesta creença. Tots es referien al singular valor agrícola del nostre medi rural (Català, 1991: 484), però tots el delimitaven com a residu després d'haver detallat amb profusió el sòl urbà i el sòl urbanitzable. Tot i que el catàleg d'elements d'interès historicoartístic, arquitectònic i paisatgístic del Pla General de 1982 inclou nombrosos elements del nostre entorn natural, com ara les torres, ermites $\mathrm{i}$ algunes poques alqueries ressenyables, no hi ha cap protecció ni posada en valor d'aquesta tipologia de manera generalitzada. Aquests fets es repetiran en els plans i catàlegs posteriors, i propiciaran l'abandonament d'aquestes edificacions, el seu espoli i el seu deteriorament. Els danys seran freqüentment irreversibles en el cas d'aquelles alqueries que no s'habitaven amb periodicitat, ni encara que fora per passar un diumenge de Pasqua.

La creixent distància mental que s'ha creat entre els veïns i veïnes de Borriana i els camps que abracen la ciutat és més que palesa en les noves generacions. La ciutat creix, engolint un medi rural que li és sovint i malauradament aliè. La planificació urbanística ha tractat el nostre terme com un full en blanc sobre el qual es pot escriure com es desitge i tant com es desitge, sense la més mínima sensibilitat cap al caràcter del territori que es manipula (Cabrera i Fenollosa, 2014: 93). La desforestació ha sigut massiva i el patrimoni rural edificat a les zones sotmeses a PAI ha estat totalment devastat, fins i tot en zones que estaven previstes com a parcs i jardins i que posteriorment han acabat amb un disseny $i$ un enjardinament absolutament mediocres (Cabrera i Fenollosa, 2014: 101).

Però, alguns exemples recents dibuixen un futur possible i optimista per a algunes de les alqueries del nostre terme. Molt estranyament, les persones que les trien com a opció habitacional continuada o temporal ho fan per a estar a prop de l'explotació agrícola, però també per a estar en contacte amb la natura i allunyar-se del bullici d'altres zones d'estiueig 
més populars i sorolloses són motius creixents. No hi ha dubte que molts exemples d'aquesta tipologia edificatòria podrien formar part de recorreguts docents i museístics, però el seu futur està clarament a recuperar el seu paper d'habitatge. Estem davant d'una tipologia suficientment resilient per a adaptar-se a moltes de les comoditats que es consideren hui en dia com a imprescindibles, i que poden posar-se així al servei d'opcions tan dràstiques com la neoruralitat o d'altres més convencionals, com el desig de gaudir de l'entorn natural i la climatologia amb què hem estat beneïts.

\section{BIBLIOGRAFIA}

Benito Goerlich, D. (1987): «La Arquitectura de 1890 a 1940», dins Mesado Oliver, N. (coord.): Burriana en su Historia 1, Borriana, Magnífic Ajuntament de Burriana, 347-365.

BordiLs, X. I S. SEVA (1998): El color en la arquitectura tradicional valenciana, València, Bancaja.

Cabrera I Fausto, I. I E. Fenollosa Forner (2014): «Urbanisme, arquitectura i patrimoni a la Borriana del canvi de Millenni», Anuari de l'Agrupació Borrianenca de Cultura, 25, 93-110.

Català Llop, B. (1991): «Historia del Planeamiento Urbanístico de Burriana», dins Mesado Oliver, N. (coord.): Burriana en su Historia 1I, Borriana, Magnífic Ajuntament de Burriana, 477-490.

García Edo, V. (1991): «Donaciones Reales y Cartas Pueblas de las Alquerías de Benihamer y Seca», dins Mesado Oliver, N. (coord.): Burriana en su Historia 1I, Borriana, Magnífic Ajuntament de Burriana, 89-97.

Del Rey I Aynat, M. (2010): Arquitectura rural valenciana, Cabrera de Mar, Galerada, Serveis d'Edició i Traducció S.C.C.L.

Guixard, P. (1987): «Los orígenes islámicos», dins Mesado Oliver, N. (coord.): Burriana en su Historia 1, Borriana, Magnífic Ajuntament de Burriana, 71-88.

Kosanović, S. i altres (2019): «A Study on the Sustainability of the Traditional Sirini'c Houses in the Šar Mountain Region, the South-Western Balkans», Sustainability, vol. 11, núm. 17, 1-16.

Martínez Morellá, V. (1951): Castillos y fortalezas de la provincia de Alicante, Alacant, Artes Gráficas Alicante.

Mesado Oliver, N. (1991): «Nuestro Campo y su Patrimonio Cultural», dins Burriana en su Historia I1, Borriana, Magnífic Ajuntament de Burriana, 153-231.

SAnchis Guarner, M. (1981): La ciutat de València: Síntesi d'història i de geografia urbana, València, Ajuntament de València.

Seijo Alonso, F. (1975): Arquitectura alicantina. El "riu-rau”, la masia, la alqueria, etc. La vivienda popular, Alacant, Ediciones Biblioteca Alicantina.

Torrent Fuertes, K. I E. Pla Vall (1987): «Evolución Urbana», dins Mesado Oliver, N. (coord.): Burriana en su Historia 1, Borriana, Magnífic Ajuntament de Burriana, 315-345.

Torrent Fuertes, K. I E. Pla Vall (1991): «Evolución de la Población en la Edad Moderna», dins Mesado Oliver, N. (coord.): Burriana en su Historia 1I, Borriana, Magnífic Ajuntament de Burriana, 275-298.

Vegas, F. I C. Mileto (2011): Aprendiendo a restaurar. Un manual de restauración de la arquitectura tradicional de la Comunidad Valenciana, València, Colegio Oficial de Arquitectos de la Comunidad Valenciana.

\section{BIONOTA}

Ivan Cabrera i Fausto (Borriana, 1974). Arquitecte per la Universitat Politècnica de València en 1998 i doctor per la mateixa institució el 2017, és professor titular del Departament de Mecànica dels Medis Continus i Teoria d'Estructures també d'aquesta universitat des de 1999 i director de l'Escola Tècnica Superior d'Arquitectura des de 2016. L'any 2010 va ser professor visitant a l'Illinois Institute of Technology 
de Chicago i en 2013 va rebre el Premi d'Excel-lència Docent del Consell Social de la UPV i de la Conselleria d'Educació, Cultura i Esport de la Generalitat Valenciana. Actualment és el president de la Conferència d'Escoles d'Arquitectura d'Espanya. Coordina la seua tasca docent amb el treball com a arquitecte al seu estudi de Borriana.

ivcabfau@mes.upv.es

Ernesto Fenollosa Forner (Almenara, 1966). Arquitecte per la Universitat Politècnica de València en 1991 i doctor per la mateixa institució el 2010. És professor titular del Departament de Mecànica dels Medis Continus i Teoria d'Estructures d'aquesta universitat des de 1994 i cap d'estudis de l'Escola Tècnica Superior d'Arquitectura des de 2016. Coordina la seua tasca docent amb el treball com a arquitecte al seu estudi de València que comparteix amb Liliana Arguedas Reula.

efenollo@mes.upv.es

Begoña Serrano Lanzarote (Argamasilla de Alba, 1965). Arquitecta per la Universitat Politècnica de València en 1992 i doctora per la mateixa institució el 2004. És professora contractada doctora del Departament de Mecànica dels Medis Continus i Teoria d'Estructures d'aquesta universitat valenciana des de 1998. Compagina la tasca docent amb la de recerca i innovació com a directora de l'Institut Valencià de l'Edificació. L'any 2008 va ser professora visitant a la Università degli Estudi di Firenze, i els anys 2016 i 2019 a la Università de la Sapienza di Roma. Va rebre el premi al millor projecte de recerca competitiu europeu del programa INTERREG -MED en 2015, un altre al millor article científic en un congrés internacional sobre rehabilitació en 2015 i el Premi d'Honor d'Arquitectura de l'Ajuntament de Pedreguer en 2019.

apserlan@mes.upv.es

Ricardo Perelló Roso (València 1965). Arquitecte per la Universitat Politècnica de València en 1991, màster en Restauració Arquitectònica per la Universitat Politècnica de Madrid i doctor novament per la Universitat Politècnica de València el 2014. És professor titular del Departament de Mecànica dels Medis Continus i Teoria d'Estructures d'aquesta universitat des de 1996. Compagina la tasca docent amb el treball professional com a arquitecte a l'estudi que comparteix a València amb Marina Sender, Manuel Giménez Ribera i Albert Albelda.

rperello@mes.upv.es 